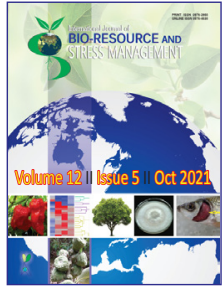

\title{
Evaluation of CROPGRO-Tomato Model under Different Dates of Planting and Cultivars under Semi-arid Environment
}

\author{
L. Shravika ${ }^{1 *}$, G. Sreenivas ${ }^{2}$, A. Madhavi ${ }^{3}$ and A. Manohar Rao ${ }^{4}$ \\ ${ }^{1}$ Dept. of Agronomy, College of Agriculture, Rajendranagar, Hyderabad, Telangana (500 030), India \\ ${ }^{2}$ Agro Climate Research Center, ARI, Rajendranagar, Hyderabad,Telangana (500 030), India \\ ${ }^{3}$ AICRP on Soil Test Crop Response, ARI, Rajendranagar, Hyderabad, Telangana (500 030), India
}

${ }^{4}$ Dept. of Horticulture, College of Agriculture, Professor JayashankarTelangana State Agricultural University, Rajendranagar, Hyderabad, Telangana (500 030), India

Open Access

Corresponding Author

L. Shravika

e-mail: shravika954@gmail.com

Citation: Shravika et al., 2021. Evaluation of CROPGRO-Tomato Model under Different Dates of Planting and Cultivars under Semi-arid Environment. International Journal of Bio-resource and Stress Management 2021, 12(5), 570-576. HTTPS://DOI. ORG/10.23910/1.2021.2412a.

Copyright: (C) 2021 Shravika et al. This is an open access article that permits unrestricted use, distribution and reproduction in any medium after the author(s) and source are credited.

Data Availability Statement: Legal restrictions are imposed on the public sharing of raw data. However, authors have full right to transfer or share the data in raw form upon request subject to either meeting the conditions of the original consents and the original research study. Further, access of data needs to meet whether the user complies with the ethical and legal obligations as data controllers to allow for secondary use of the data outside of the original study.

Conflict of interests: The authors have declared that no conflict of interest exists.

\begin{abstract}
A field investigation was undertaken during Kharif (June-September) 2019 at Agriculture Research Institute, Professor Jayashankar Telangana State Agriculture University, Rajendranagar, Hyderabad, Telengana State, India with an object to evaluate the CROPGRO-Tomato model under different dates of planting and cultivars. The experiment was carried out with dates of planting $\left(02^{\text {nd }} \mathrm{Jul}, 12^{\text {th }} \mathrm{Jul}\right.$, $22^{\text {nd }} \mathrm{Jul}, 02^{\text {nd }} \mathrm{Aug}, 11^{\text {th }} \mathrm{Aug}, 23^{\text {rd }} \mathrm{Aug}, 03^{\text {rd }} \mathrm{Sep}$ and $13^{\text {th }} \mathrm{Sep}$ ) as main plot treatments and cultivars US 440 and TO-3251 (Saaho) as sub-plot treatments. The CROPGROTomato model performed well in the simulation of phenology, biomass, fruit yield and N uptake during calibration for US 440 and TO-3251.Calibration results revealed that the model perfectly predicted days to anthesis with no difference between simulated and observed data for both cultivars with RMSE of 0 days, the further model simulated the days to last picking,biomassat maturity, fruit yield and nitrogen uptake with RMSE of 0.9 and 0.7 day, 285 and $435 \mathrm{~kg} \mathrm{ha}^{-1}, 545 \mathrm{~kg}$ $\mathrm{ha}^{-1}$ and $389 \mathrm{~kg} \mathrm{ha}^{-1}$ (dry weight), 6 and $5 \mathrm{~kg} \mathrm{ha}^{-1}$ for US 440 and TO-3251 cultivars respectively. The calibrated model was used to further validate the experimental data and found that, simulation of days to anthesisand days to the last picking was excellent with NRMSE value of less than $10 \%$ for both cultivars,fair with dry matter production with NRMSE value of $25 \%$ for both cultivars and was poor with total fruit yield greater than $30 \%$ and $\mathrm{N}$ uptake for both cultivars under study was poor with NRMSE value more than $30 \%$.
\end{abstract}

Keywords: Biomass, CROPGRO-tomato, cultivars, dates of planting, phenology, yield

\section{Introduction}

Tomato (Solanum lycopersicum L.) is the second largest cultivated vegetable crop and one of the most widely consumed vegetable in the World after potato. Tomato can play an important role in human diet and known as protective food because of its special nutritive value and alsoit's wide spread production. Itwas an excellent sources of vitamin A, C and $\mathrm{K}$ along with good sources of antioxidants and phyto-chemical compounds, including lycopene, $\beta$-carotene and flavonoids (Chandni et al., 2020).

Tomato (Solanum lycopersicum L.) is one of the most popular and widely

Article History

RECEIVED on $09^{\text {th }}$ June 2021 RECEIVED in revised form on $15^{\text {th }}$ October 2021 ACCEPTED in final form on $30^{\text {th }}$ October 2021 
grown vegetable crops in the World (Chattopadhyay and Paul, 2012). The global production of fresh and processing tomatoes increased by $300 \%$ during the last four decades (Costa and Heuvelink, 2007), reaching around 160 million tons in 2017 (Pathak and Stoddard, 2018).India is the third largest producer of tomato in the world after USA and China (Sharma et al., 2019). Tomato is one of the most important protective food crops of India having an area of 880 thousand hectares with an annual production to the tune of 18227 thousand metric tonnes, contributing to $9.4 \%$ of total vegetable area and $11.5 \%$ of total vegetable production. The productivity of tomato in India (19.6 $\mathrm{mt} \mathrm{ha}^{-1}$ ) is much less than the average productivity (28.2 $\mathrm{mt} \mathrm{ha}^{-1}$ ) of the world (Anonymous, 2009). In Telangana, it occupies an area of 41,480 hectares primarily under irrigated conditions with a productivity of $28.24 \mathrm{mt} \mathrm{ha}^{-1}$ (Anonymous, 2018)

Traditional agronomic experiments are conducted at particular points in time and space, making results site and season specific, time consuming and expensive.In recent years, several process based dynamic crop simulation models has been developed that predict crop growth, development and yield using a systems approach, where that integrates the knowledge of underlying processes and interaction of different components of crop production. Simulation modeling can be a powerful tool to analyze the relationships among soil, plants, air, and other components in agricultural systems, particularly through studying the relationships between system components over time (Lenz-Wiedemann et al., 2010). In the last decades, several tomato models have been focused on different research topics e.g., TOMGRO, TOMSIM, TOMPOUSSE and CROPGRO-Tomato (Boote et al., 2012). Scholberg et al. (1997) adapted the CROPGRO-Peanut model for establishing CROPGRO-Tomato model to simulate growth, yield and yield components of the fieldgrown tomatoes. Modeling the growth of field-grown tomatoes should assist growers and extension workers throughout the world to outline optimal crop management strategies for specific locations and production systems. These models were developed, not only to understand the processes and interactions involving system components and their effects upon overall production, but also for their usefulness as decision support tools for identifying best management options for attaining optimal production (Deligios et al., 2012). Among various crop growth models, CROPGRO-Tomato model was used to calibrate and validate the growth, development and fruit yield of tomato in different parts of India (Safia, 2015). For this region, DSSAT CERES-Maize model was used to calibrate and evaluate the popular maize hybrid (Rani et al., 2016) and further this validated model was used to identify the optimum sowing window and nitrogen levels under rainfed conditions in a semi-arid environment (Rani et al., 2014). However, So far no such model was used for the tomato to calibrate and validate the experimental data for this region with popular cultivars in order to make management decisions to improve the productivity under open field conditions. Keeping the above points in view the present study was conducted to calibrate and evaluate the CROPGRO-Tomato model using experimental data.

\section{Materials and Methods}

The field experiment was conducted at Agricultural Research Institute, Rajendranagar, Hyderabad, Telengana State, India during 2019 kharif (June-September) having 17019' N Latitude, $78^{\circ} 23^{\prime}$ E Longitude and $542.3 \mathrm{~m}$ above mean sea level. The experiment was laid out in split plot design with eight dates of planting (02 ${ }^{\text {nd }} \mathrm{Jul}, 12^{\text {th }} \mathrm{Jul}, 22^{\text {nd }} \mathrm{Jul}, 02^{\text {nd }}$ Aug, $11^{\text {th }}$ Aug, $23^{\text {rd }}$ Aug, $03^{\text {rd }}$ Sep and $13^{\text {th }}$ Sep) as main treatments and two cultivars (US 440 and TO-3251) as sub treatments, replicated thrice. The soil of the experimental site was sandy loam in texture, neutral in reaction, low in available nitrogen, phosphorus and high in available potassium. The other package of practices wereusedasfor the recommendations for raising the crop.

In the present experiment to assess the role of simulation models in agronomic research, the Decision Support System for Agro-technology Transfer (DSSAT) v4.7 CROPGROTomato model was used. The model was calibrated using an iterative approach proposed by Hunt et al. (1993) and Godwin et al. (1989) togeneratea suitable set of coefficients through trial and error adjustments to match the observed crop phenology and yield with those simulated by the model.

Statistically based criteria provide a more objective method to evaluate the performance of themodel (Ducheyne, 2000). Simulation performance was evaluated by calculating test statistics like root mean square error (RMSE) (Wallach and Goffinet, 1989). Time course simulation of crop biomass and fruit yield was assessed by an index of agreement (d) (Willmott, 1982) that is an aggregate overall indicators. These measurements were calculated as follows.

$$
\begin{aligned}
& \text { RMSE }=\left[\sum_{i=1}^{n}\left(p_{i}-O_{i}\right)^{2} / n\right]^{0.5} \\
& d=1-\left[\frac{\left[\sum_{i=1}^{n}\left(p_{i}-O_{i}\right)^{2}\right.}{\left[\sum_{i=1}^{n}\left(\left|p_{i}^{\prime}\right|+\left|O_{i}^{\prime}\right|\right)^{2}\right.}\right]
\end{aligned}
$$

Where $\mathrm{P}_{i}$ and $\mathrm{O}_{i}$ are the predicted and observed values for studied variables, respectively and $n$ is the number of observations. Model performance improved as $d$ value approaches to unity. A smaller RMSE indicated less deviation of the simulated from the observed values. Normalized RMSE (NRMSE) gives a measure (\%) of the relative difference of simulated versus observed data. The simulation is considered excellent with a normalized RMSE less than $10 \%$, good if the normalized RMSE is greater than 10 and less than $20 \%$, fair if the normalized RMSE is greater than $20 \%$ and less than $30 \%$, and poor if the normalized RMSE is greater than $30 \%$ (Loague and Green, 1991). The NRMSE 
was calculated following equation.

Normalized Root Mean Square Error $=\left[\frac{\mathrm{RMSE}}{\overline{\mathrm{O}}}\right] \times 100$

The Coefficient of Residual Mass (CRM) was used to measure the tendency of the model to overestimate or underestimate the measured values. The CRM is defined by

$\mathrm{CRM}=\frac{\left[\sum_{i=1}^{n}\left(O_{i}-\sum_{i=1}^{n} P_{i}\right)^{2}\right.}{\sum_{i=1}^{n} O_{i}}$

Where, $\mathrm{O}_{i}$ and $\mathrm{P}_{i}$ are the observed and predicted values respectively for the $i^{\text {th }}$ data point of $n$ observations. A negative CRM indicates a tendency of the model towards overestimation (Xevi et al., 1996).

\section{Results and Discussion}

\subsection{Calibration of genetic coefficients}

For calibrationof genetic coefficients of US 440 and TO-3251 was estimated by repeated iterations until a close match between simulated and observed phenology, growth and yield was obtained.The CROPGRO-Tomato model performed well in the simulation of growth, phenology, fruit yield and biomass during the calibration process across the first four planting dates $D_{1}(02 \mathrm{Jul}), D_{2}$ (12 Jul), $D_{3}$ (22 Jul) and $D_{4}$ (02 Aug) for US
440 and TO-3251. The genetic coefficients of selected cultivars were presented in Table 1. Calibration results revealed that (Table 2) model perfectly predicted days to anthesis with no difference between simulated and observed data for cultivars US 440 and TO-3251 with RMSE of 0 days between simulated and observed values across different planting dates. CROPGRO-Tomato model showed excellent simulated having less than one day difference with RMSE of 0.9 and 0.7 days for US 440 and TO-3251 respectively.

The simulation of crop biomass at maturity was also match well with RMSE of 285 and $435 \mathrm{~kg} \mathrm{ha}^{-1}$ for US 440 and TO-3251 respectively. There was a good agreement between observed and simulated fruit yield with RMSE of $545 \mathrm{~kg} \mathrm{ha}^{-1}$ and 389 $\mathrm{kg} \mathrm{ha}^{-1}$ (dry weight) for US 440 and TO-3251 respectively. In the case of nitrogen uptake simulation was well with RMSE values of 6 and $5 \mathrm{~kg} \mathrm{ha}^{-1}$ for US 440 and TO-3251 respectively. In all the cases the $d$-stat value was $\geq 0.70$.

\subsection{Model validation}

CROPGRO-Tomato model was validated with the data sets obtained from the remaining dates of planting $D_{5}$ (11 Aug), $D_{6}$ (23 Aug), $D_{7}$ (03 Sep) and $D_{8}$ (13 Sep) from the experiment conducted during the year 2019 with two cultivars (US 440 and TO-3251). The corresponding simulation results were

\begin{tabular}{|c|c|c|c|}
\hline $\begin{array}{l}\text { Coeffi- } \\
\text { cients }\end{array}$ & Description of coefficients & US 440 & TO-3251 \\
\hline CSDL & $\begin{array}{l}\text { Critical Short Day Length below which reproductive development progresses with no day length } \\
\text { effect (for short day plants) (hour) }\end{array}$ & 12.33 & 12.33 \\
\hline PPSEN & $\begin{array}{l}\text { Slope of the relative response of development to photoperiod with time (positive for short } \\
\text { day plants) (1/hour) }\end{array}$ & 0.00 & 0.00 \\
\hline EM-FL & Time between plant emergence and flower appearance (R1) (photo thermal days) & 24.0 & 24.0 \\
\hline FL-SH & Time between first flower and first pod (R3) (photo thermal days) & 4.9 & 4.0 \\
\hline FL-SD & Time between first flower and first seed (R5) (photo thermal days) & 26.0 & 21.0 \\
\hline SD-PM & Time between first seed (R5) and physiological maturity (R7) (photo thermal days) & 37.5 & 41.0 \\
\hline FL-LF & Time between first flower (R1) and end of leaf expansion (photo thermal days) & 52.0 & 52.0 \\
\hline LFMAX & Maximum leaf photosynthesis rate at $30 \mathrm{C}, 350 \mathrm{vpm} \mathrm{CO}_{2}$, and high light $\left(\mathrm{mg} \mathrm{CO}_{2} \mathrm{~m}^{-2}\right.$-s) & 1.40 & 0.95 \\
\hline SLAVR & Specific leaf area of cultivar under standard growth conditions ( $\mathrm{cm} 2 \mathrm{~g}-1)$ & 325.0 & 330.0 \\
\hline SIZLF & Maximum size of full leaf (three leaflets) $\left(\mathrm{cm}^{2}\right)$ & 325.0 & 800.0 \\
\hline XFRT & Maximum fraction of daily growth that is partitioned to seed + shell & 0.90 & 0.73 \\
\hline WTPSD & Maximum weight per seed (g) & 0.0040 & 0.0030 \\
\hline SFDUR & Seed filling duration for pod cohort at standard growth conditions (photo thermal days) & 28.5 & 26.0 \\
\hline SDPDV & Average seed per pod under standard growing conditions (\#/pod) & 300.0 & 300.0 \\
\hline PODUR & Time required for cultivar to reach final pod load under optimal conditions (photo thermal days) & 56.0 & 58.0 \\
\hline THRSH & $\begin{array}{l}\text { Threshing percentage. The maximum ratio of (seed/ (seed }+ \text { shell) at maturity. Causes seed to } \\
\text { stop growing as their dry weight increases until the shells are filled in a cohort. }\end{array}$ & 7.3 & 5.4 \\
\hline SDPRO & Fraction protein in seeds (g (protein) $\mathrm{g}^{-1}$ (seed)) & 0.350 & 0.350 \\
\hline SDLIP & Fraction oil in seeds (g(oil) $\mathrm{g}^{-1}$ (seed)) & 0.050 & 0.090 \\
\hline
\end{tabular}


Table 2: Observed and predicted phenology, biomass, fruit yield and $\mathrm{N}$ uptake after calibration of CROPGRO-Tomato model

\begin{tabular}{|c|c|c|c|c|}
\hline Parameter & Simulated & Observed & RMSE & d-sta \\
\hline \multicolumn{5}{|l|}{$\mathrm{V}_{1}$ (US 440) } \\
\hline Days to anthesis & 26 & 26 & 0 & 0.9 \\
\hline Days to last picking & 103 & 103 & 0.7 & 0.9 \\
\hline $\begin{array}{l}\text { Biomass at } \\
\text { maturity }\left(\mathrm{kg} \mathrm{ha}^{-1}\right)\end{array}$ & 2310 & 2378 & 285 & 0.9 \\
\hline $\begin{array}{l}\text { Fruit yield }\left(\mathrm{kg} \mathrm{ha}^{-1}\right) \\
\text { (DW) }\end{array}$ & 1510 & 1439 & 545 & 0.7 \\
\hline $\begin{array}{l}\text { Nitrogen uptake } \\
\left(\mathrm{kg} \mathrm{ha}^{-1}\right)\end{array}$ & 41 & 38 & 6 & 0.9 \\
\hline \multicolumn{5}{|l|}{$V_{2}(\mathrm{TO}-3251)$} \\
\hline Days to anthesis & 26 & 26 & 0 & 0.9 \\
\hline Days to last picking & 102 & 103 & 0.5 & 0.7 \\
\hline $\begin{array}{l}\text { Biomass at } \\
\text { maturity }\left(\mathrm{kg} \mathrm{ha}^{-1}\right)\end{array}$ & 1885 & 2302 & 435 & 0.8 \\
\hline $\begin{array}{l}\text { Fruit yield }\left(\mathrm{kg} \mathrm{ha}^{-1}\right) \\
\text { (DW) }\end{array}$ & 1286 & 1225 & 389 & 0.8 \\
\hline $\begin{array}{l}\text { Nitrogen uptake } \\
\left(\mathrm{kg} \mathrm{ha}^{-1}\right)\end{array}$ & 37 & 38 & 5 & 0.9 \\
\hline
\end{tabular}

explained as under and the statistical indices were presented below.

\subsection{Days to anthesis}

Simulated value of days to anthesis was closer to the observed data, with RMSE value of 0.5 days, CRM value of -1 and NRMSE of $2 \%$. This clearly showed that, CROPGRO-Tomato model overestimated the days to anthesis to the extent of $1 \%$. However, under the present study simulation of days to anthesis was considered excellent as the normalized RMSE (NRMSE) value was less than $10 \%$ for both cultivars (Table 3 ).

\subsection{Days to last picking}

A difference of 2 days was noticed between observed and simulated values to attain the last pickingfor cultivar US 440 with RMSE, NRMSE and CRM values of 2 days, $2 \%$ and 1 day respectively, showed the tendency of the model to underestimate the days to the last picking by 1 day. For cultivar TO-3251 the difference of only 3 days was noticed between observed and simulated values to attain the last pickingwith RMSE, NRMSE and the CRM values of 3 days, $3 \%$ and 2 days respectively and this showed the tendency of the model to underestimate the days to last picking by 2 days. However, for both cultivars, the simulation was considered excellent with an NRMSE value of less than 10\% (Table 4).

\subsection{Biomass at maturity}

The RMSE value of $570 \mathrm{~kg} \mathrm{ha}^{-1}$ reflected that the model
Table 3: Comparison of simulated and observed days to anthesis of tomato under different dates of planting and cultivars

\begin{tabular}{|c|c|c|c|}
\hline Treatment & Simulated & Observed & Difference \\
\hline \multicolumn{4}{|l|}{$\mathrm{V}_{1}$ (US 440) } \\
\hline$D_{5}\left(11^{\text {th }}\right.$ Aug $)$ & 26 & 25 & 1 \\
\hline$D_{6}\left(23^{\text {rd }}\right.$ Aug $)$ & 27 & 27 & 0 \\
\hline$D_{7}\left(03^{\text {rd }}\right.$ Sep $)$ & 27 & 27 & 0 \\
\hline$D_{8}\left(13^{\text {th }}\right.$ Sep $)$ & 27 & 27 & 0 \\
\hline RMSE & & 0.5 & \\
\hline NRMSE & & 2 & \\
\hline CRM & & -1 & \\
\hline \multicolumn{4}{|l|}{$\mathrm{V}_{2}(\mathrm{TO}-3251)$} \\
\hline$D_{5}\left(11^{\text {th }}\right.$ Aug $)$ & 26 & 25 & 1 \\
\hline$D_{6}\left(23^{\text {rd }}\right.$ Aug $)$ & 27 & 27 & 0 \\
\hline$D_{7}\left(03^{\text {rd }}\right.$ Sep $)$ & 27 & 27 & 0 \\
\hline$D_{8}\left(13^{\text {th }}\right.$ Sep $)$ & 27 & 27 & 0 \\
\hline RMSE & & 0.5 & \\
\hline NRMSE & & 2 & \\
\hline CRM & & -1 & \\
\hline
\end{tabular}

Table 4: Comparison of simulated and observed days to the last picking of tomato under different dates of planting and cultivars

\begin{tabular}{lccc}
\hline Treatment & Simulated & Observed & Difference \\
\hline $\mathrm{V}_{1}($ US 440) & & & \\
\hline $\mathrm{D}_{5}\left(11^{\text {th }}\right.$ Aug $)$ & 102 & 102 & 0 \\
$\mathrm{D}_{6}\left(23^{\text {rd }}\right.$ Aug $)$ & 103 & 102 & 1 \\
$\mathrm{D}_{7}\left(03^{\text {rd }}\right.$ Sep $)$ & 101 & 104 & -3 \\
$\mathrm{D}_{8}\left(13^{\text {th }}\right.$ Sep $)$ & 105 & 106 & -1 \\
RMSE & & 2 & \\
NRMSE & & 2 & \\
CRM & & 1 & \\
$V_{2}($ TO-3251 $)$ & & & \\
\hline$D_{5}\left(11^{\text {th }}\right.$ Aug $)$ & 100 & 102 & -2 \\
$D_{6}\left(23^{\text {rd }}\right.$ Aug $)$ & 102 & 102 & 0 \\
$D_{7}\left(03^{\text {rd }}\right.$ Sep $)$ & 100 & 104 & -4 \\
$D_{8}\left(13^{\text {th }}\right.$ Sep $)$ & 103 & 106 & -3 \\
RMSE & & 3 & \\
NRMSE & & 3 & \\
CRM & & 2 & \\
\hline
\end{tabular}

predicted above-ground biomass was quite good. The simulation of biomass at maturity stage was considered as fair with an NRMSE value of $25 \%$ for cultivar US 440 due to 
overestimation of biomass by $16 \%$ with CRM value of $-16 \%$ (Figure 1).

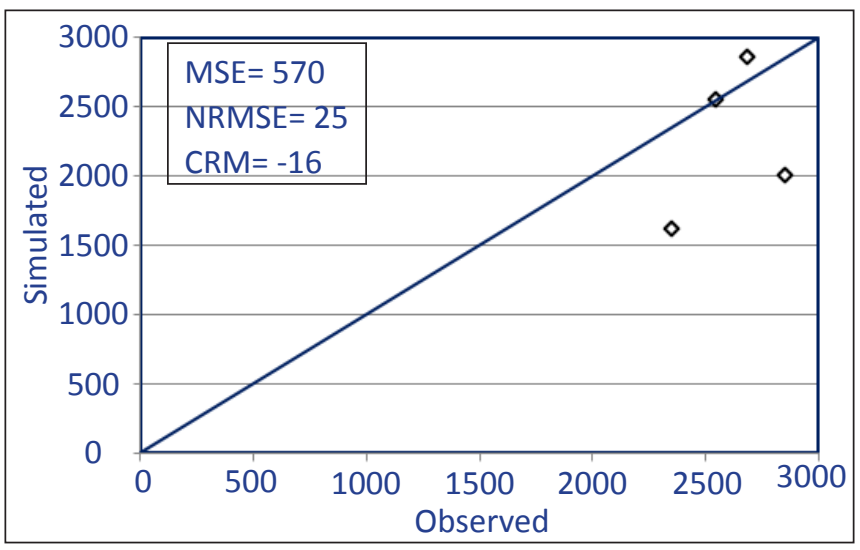

Figure 1: Simulated and observed biomass $\left(\mathrm{kg} \mathrm{ha}^{-1}\right)$ of cultivar US 440 at first Picking phase using CROPGRO-Tomato model under different dates of planting

For cultivar TO-3251 the RMSE value of $519 \mathrm{~kg} \mathrm{ha}^{-1}$ revealed that the model predicted the above-ground biomass was fair with an NRMS value of $25 \%$. This fair simulation was due to the underestimation of biomass by $3 \%$ with a CRM value of 3 (Figure 2). Similar results were reported by Sunil et al. (2006) from IARI with fair simulation between observed and simulated biomass. It might be due to the extensive data requirements and more sophisticated nature of the model.

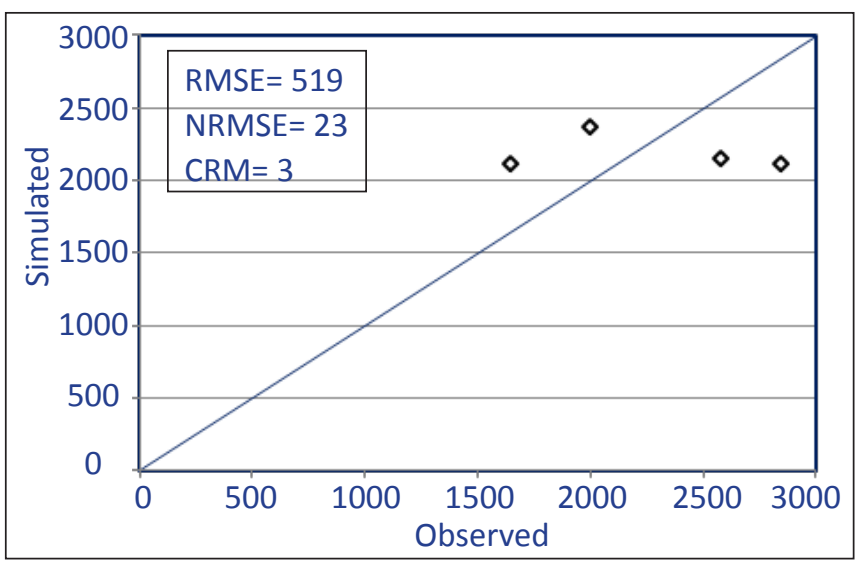

Figure 2: Simulated and observed biomass $\left(\mathrm{kg} \mathrm{ha}^{-1}\right)$ of cultivar TO-3251 at first Picking phase using CROPGRO-Tomato model under different dates of planting

\subsection{Fruit yield}

Simulated fruit yield was varied with the observed data with an RMSE value of $771 \mathrm{~kg} \mathrm{ha}^{-1}$ (dry weight). The simulation of fruit yield at the maturity stage was considered as poor with an NRMSE value of $59 \%$ for cultivar US 440 due to overestimation of the fruit yield by $46 \%$ with a CRM value of -46 (Figure 3).

In a similar waycultivar TO-3251 also showed the same trend with an RMSE value of $689 \mathrm{~kg} \mathrm{ha}^{-1}$ (dry weight). Here also the simulation of fruit yield at maturity stage was considered as

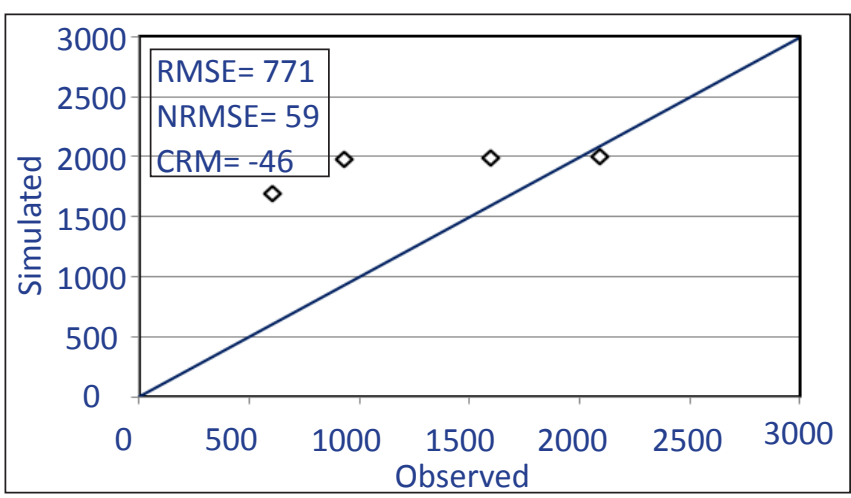

Figure 3: Simulated and observed fruit yield $\left(\mathrm{kg} \mathrm{ha}^{-1}\right)$ of cultivar US 440 using CROPGRO-Tomato model under different dates of planting

poor with an NRMSE value of $56 \%$ due to overestimation of the fruit yield by $26 \%$ with a CRM value of -26 (Figure 4). Elsayedet al. (2017) from northeastern Italy also reported high RMSE values during validation of the CROPGRO-Tomato model.

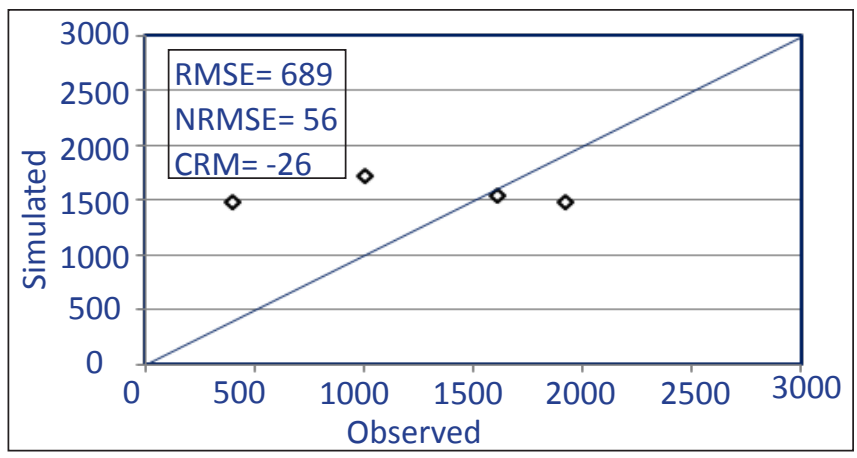

Figure 4: Simulated and observed fruit yield $\left(\mathrm{kg} \mathrm{ha}^{-1}\right)$ of cultivar TO-3251 using CROPGRO-Tomato model under different dates of planting

\subsection{Nitrogen uptake}

Simulated nitrogen uptake was closely related to the observed data with an RMSE value of $18 \mathrm{~kg} \mathrm{ha}^{-1}$. The simulation of nitrogen uptake at the maturity stage was considered as poor with an NRMSE value of $49 \%$ for cultivar US 440 due to overestimation of the $N$ uptake by $48 \%$ with a CRM value of -48 (Figure 5).

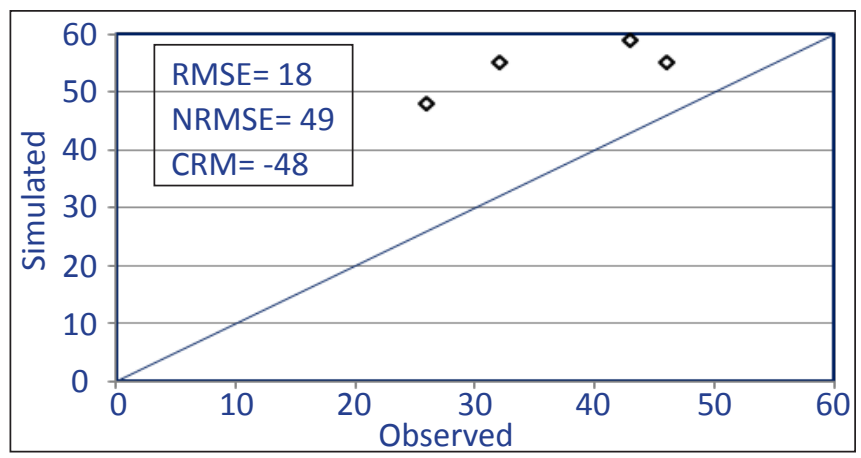

Figure 5: Simulated and observed $\mathrm{N}$ uptake $\left(\mathrm{kg} \mathrm{ha}^{-1}\right)$ of cultivar US 440 at first Picking phase using CROPGRO-Tomato model under different dates of planting 
Cultivar TO-3251 also showed a similar trend as that of US440 with an RMSE value of $15 \mathrm{~kg} \mathrm{ha}^{-1}$. Here also the simulation of nitrogen uptake at maturity stage was considered as poor with an NRMSE value of $39 \%$ due to overestimated the $\mathrm{N}$ uptake by $30 \%$ with a CRM value of -30 (Figure 6 ).

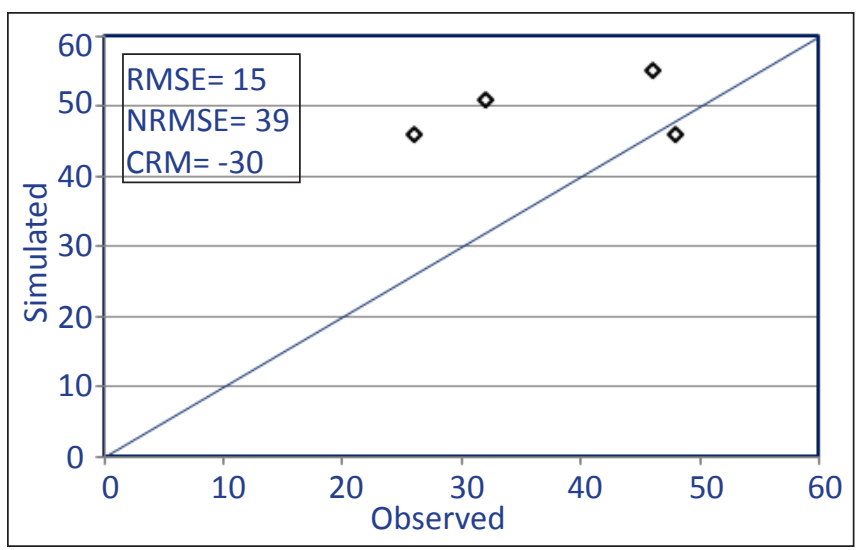

Figure 6: Simulated and observed N uptake $\left(\mathrm{kg} \mathrm{ha}^{-1}\right)$ of cultivar TO-3251 at first Picking phase using CROPGRO-Tomato model under different dates of planting

\section{Conclusion}

Calibration of CROPGRO-Tomato model for days to anthesis, days to the last picking, dry matter production, fruit yield and $\mathrm{N}$ uptake for both cultivars was found reasonably good with low RMSE values and d-statistics value of $\geq 0$.7. Validation of the CROPGRO-Tomato model revealed that model performance was excellent with phenology, fair with dry matter production. Whereas it was poor with $\mathrm{N}$ uptake and total fruit yield for both cultivars as the model overestimation.

\section{References}

Anonymous, 2009. Indian horticulture database. NHB, Department of Agriculture Cooperation, Ministry of Agricultureand Farmers Welfare. Government of India. Available at http://pphouse.org/ijbsm-article-details. php?article $=233$.

Anonymous, 2018. Horticultural statistics at a glance. Statistics Division.Government of India. Available at https:// agricoop.nic.in/sites/default/files/Horticulture\%20 Statistics\%20at\%20a\%20Glance-2018.pdfAccessed on 13.07.2021.

Boote, K.J., Rybak, M.R., Scholberg, J.M.S., Jones, J.W., 2012. Improving the CROPGRO-tomato model for predicting growth and yield response to temperature. HortScience 47, 1038-1049.

Chandni, Singh, D., Akhtarand, S., Dutta, S.K., 2020. Effect of microclimate on yield and quality attributes of cherry tomato (Solanum lycopersicum L. var. cerasiforme) under Open field and polyhouse conditions. International Journal of Environment and Climate Change 10(4), 24-30.
Chattopadhyay, A., Paul, A., 2012. Studies on heterosis in tomato (Solanumlycopersicum). International Journal of Bio-resource and Stress Management 3(3), 278-283.

Costa, J.M., Ortuno, M.F., Chaves, M.M., 2007. Deficit irrigation as a strategy to save water: physiology and potential application to horticulture.Journal of Integrative Plant Biology 49, 1421-1434.

Deligios, P.A., Cossu, M., Murgia, L., Sirigu, A., Urracci, G., Pazzona, A., Palal, T., Ledda, L., 2017. Modeling tomato growth and production in a photovoltaic greenhouse in southern Italy.Acta Horticulture 1182, 203-210. DOI 10.17660/ActaHortic.2017.1182.24.

Ducheyne, S., 2000. Derivation of the parameters of the WAVE model using a deterministic and a stochastic approach. PhD thesis. Faculty of Agriculture and Applied Biological Sciences, K.U. Leuven, Belgium.

Elsayed, M., Mahmoud, M.B., Gerrit, H., Michele, R., Stefano, B., Paolo, S., 2017. Assessment of transplanting date influence on processing tomato (Lycopersicon esculentum Mill.) production using the cropping system model (CSM)-CROPGRO-tomato simulation model a case study for Northeastern Italy. Egypt Journal of Soil Science 4, 429-442.

Godwin, D.C., Ritchie, J.T., Singh, U., Hunt, L.A., 1989. A user's guide to CERES-Wheat v2.10. International Fertilizer Development Center, Muscle Shoals, A1.

Hunt, L.A., Parajasingham, S., Jones, J.W., Hoogenboom, G., Imamura, D.T., Ogoshi, R.M., 1993. Gencalc-Software to facilitate the use of crop models for analyzing field experiments. Agronomy Journal 85, 1090-1094.

Lenz-Wiedemann, V.I.S., Klar, C.W., Schneider, K., 2010. Development and test of a crop growth model for application within a global change decision support system. Ecological Modelling 221(2), 314-329. https:// doi.org/10. 1016/j.ecolmodel.2009.10.014.

Loague, K., Green, R.E., 1991. Statistical and graphical methods for evaluating solute transport models: Overview and application. Journal of Contaminant Hydrology 7, 51-73.

Pathak, T.B., Stoddard, C.S., 2018. Climate change effects on the processing tomato growing season in California using growing degree day model. Modeling Earth Systems and Environment 4, 765-775.

Rani, P.L., Sreenivas, G., Reddy, D.R., 2016. Calibration and validation of CERES-maize model for hybrid maize under variable plant densities and nitrogen level in Southern Telangana Zone of Telangana State, India. International Journal of Bio-resource and Stress Management 7(2), 212-217.

Rani, P.L., Sreenivas, G., Reddy, D.R., 2014. Application of CSM-CERES-Maize model to define a sowing window and nitrogen rates for rainfed maize in semi-arid environment. International Journal of Bio-resource and Stress Management 5(2), 181-185. 
Safia, M., 2015. Modeling the impact of climate change on growth and yield of tomato.MSc.Thesis. Kerala Agricultural University, Thrissur, Kerala.

Scholberg, J.M.S., Boote, K.J., Jones, J.W., McNeal, B.L., 1997. Adaptation of the CROPGRO model to simulate the growth of field-grown tomato. In: Kropff, M.J. et al. (Eds.), Systems approaches for sustainable agricultural development: applications of systems approaches at the field level. Kluwer Academic Publishers, Dordrecht, The Netherlands, 133-151.

Sharma, A., Raina, R., Kapoor, R., Singh T.K., 2019. Evaluation of poison baits and Bacillus thuringiensis var. kurstaki against Spodoptera litura in tomato. International Journal of Economic Plants 6(4), 186-190.
Sunil, K.M., Sarma, S., Balrajsingh, K.S., 2006. Simulating the effect of thermal environment on tomato with CROPGRO (DSSAT V4) model.Annals of Agricultural Research New Series 27(1), 63-66.

Wallach, D., Goffinet, B., 1989. Mean squared error of prediction as a criterion for evaluating and comparing system models. Ecological Modelling 44, 200-306.

Willmott, C.J., 1982. Some comments on the evaluation of model performance. Bulletin in American Meteorologcal Society 63, 1309-1313.

Xevi, E., Gilley, J., Feyen, J., 1996. Comparative study of two crop yield simulation models. Agricultural Water Management 30, 155-173. 